\title{
HALL OF FAME INDUCTEES
}

\author{
Willard S. Boyle
}

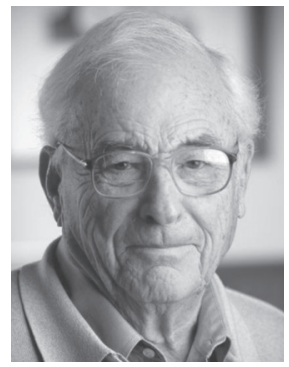

Born: 19 August 1924, Amherst, Nova Scotia

Died: 7 May 2011, Truro, Nova Scotia

Field: Physics, Semiconductor technology

Willard Boyle moved to rural Quebec as a young boy, was home schooled by his mother, and began his formal education at Lower Canada College in Montreal at the age of 14. He joined the Royal Canadian Navy in 1943. After the war, he received his B.Sc., M.Sc and PhD (Physics) degrees from McGill University. In 1953, h joined the Bell Laboratories in Murray Hill, New Jersey, USA.

In 1962, he worked on a project which developed the first continuously operating ruby laser. He participated in space science and exploratory programs and the Apollo Space program. In 1969, in collaboration with colleague George Smith, the charge-coupled device (CCD) was created. During his time at the Bell Laboratories, he was involved in producing at least 18 patents. He retired from the Bell Laboratories in 1979 as the Executive Director of the Communication Science Division. He then lived in Wallace, Nova Scotia and maintained a residence in Lac Tremblant, Quebec.

For his contributions to science, Dr. Boyle received numerous awards, medals, and prizes. He was inducted into the Canadian Science \& Engineering Hall of Fame in 2005. He was the co-recipient of the Nobel Prize in Physics in 2009 for his role in the invention of an imaging semiconductor circuit - the CCD sensor. He was made a Companion of the Order of Canada in 2010. 


\section{Kenneth Henry Mann}

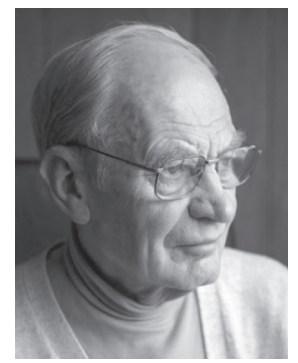

Born: 15 August 1923, Dovercourt, UK

Died: 24 January 2010, Halifax, Nova Scotia

Field: Marine Ecology

Dr. Mann was associated with the Zoology Department at Reading University (1954-1966) and his biological research soon led him to studies on aquatic ecosystems. He received a research grant to study the ecosystem energy-flow of the Thames River as a part of the International Biological Programme(IBP); this enabled him to observe web structure and function in different aquatic systems. In 1967, a year after Canada became a member of the IBP, he immigrated to Canada and accepted a position at the Bedford Institute of Oceanography (BIO), Marine Ecology Laboratory, as the Head of Biological Oceanography. His research was to measure and model marine production of multiple trophic levels from plankton and benthos to fish in St. Margaret's Bay, Nova Scotia. His research provided the first quantitative data to show that macrophytes were an important source of dissolved and particulate organic material providing energy for coastal marine food webs. He was Professor and Chairman of Biology at Dalhousie University from 1972-1980 and from 1980-1987 was the Director of the Marine Ecology Laboratory, Dept. of Fisheries and Oceans, at BIO.

Dr. Mann received a D.Sc. from the University of London (1965), and an honorary doctorate from Cape Breton University (2008). He was the first recipient of the Lifetime Achievement Award from the American Society of Limnology and Oceanography (1995). He received the Gulf of Maine Council's Visionary Award in 2003. He was a Fellow of the Royal Society of Canada. 